\title{
Microtubule-Associated Proteins 1A/1B Light Chain 3B
}

National Cancer Institute

\section{Source}

National Cancer Institute. Microtubule-Associated Proteins 1A/1B Light Chain 3B. NCl

Thesaurus. Code C116660.

Microtubule-associated proteins 1A/1B light chain 3B (125 aa, $15 \mathrm{kDa})$ is encoded by the human MAP1LC3B gene. This protein is involved in the both catabolism of mitochondria and autophagy. 